\title{
Effects of the Determinants of Foreign Direct Investment in Nigeria: Error Correction Mechanism
}

\author{
Kolawole Ebire $^{1^{*}}$, O Lucky Onmonya ${ }^{1}$ and V Ekemini Inim ${ }^{2}$ \\ ${ }^{1}$ Institute of Development Finance and Project Management, Nigeria \\ 2International Organisation of Migration, Nigeria \\ *Corresponding author: Kolawole Ebire, Institute of Development Finance and Project Management, Nigeria, Tel: +2347065681464; E-mail: \\ Kolawole.ebire@gmail.com
}

Received Date: Jul 24, 2018; Accepted Date: Nov 23, 2018; Published Date: Nov 30, 2018

Copyright: (c) 2018 Ebire $\mathrm{K}$, et al. This is an open-access article distributed under the terms of the Creative Commons Attribution License, which permits unrestricted use, distribution, and reproduction in any medium, provided the original author and source are credited.

\begin{abstract}
Most nations all over the world institutes policies to attract more Foreign Direct Investment (FDI) inflows. Identifying the key determinants of FDI inflows is therefore seen as an important task for policy makers. This study therefore, investigates the major determinants of FDI in Nigeria spanning from 1986-2017. Secondary source of data were used for the study which were first subjected to stationarity test using Augmented Dickey Fuller and Phillips Perron test. Findings showed that all variables were found to be integrated into the order of one. Cointegration analysis showed that there exist a long run relationship among the variables. Based on these findings, Error Correction Mechanism was used in testing the hypotheses. The result showed that exchange rate, GDP, first lag of GDP, military expenditure, first lag of military expenditure, political stability and financial development are the major determinants of FDI inflows to Nigeria. The study therefore recommends among others that, government at all levels should tackle the menace of insecurity ravaging the economy and portraying the country as insecure thereby creating a secured environment for FDI inflows. Democratic regimes should be sustained and investment policies should be instituted or improved on, in order to create a friendly environment to attract more FDI inflows.
\end{abstract}

Keywords: Foreign direct investment; GDP; Error correction mechanism; Nigeria

\section{Introduction}

Foreign Direct Investment (FDI) over the years have received increased attention which is been described as a key element of globalization, and also a driver of employment opportunities, technological transfer, productivity, and ultimately economic growth [1]. FDI has proven to possess the capability to increase tax revenues and improve management, technology, as well as labor skills in host countries as opined by Hayami and, Todaro and Stephen [2,3]. In order to achieve these benefits, countries strategically position themselves by creating an investment friendly environment through various policies and regulations. The Organization for Economic Co-operations and Development [4] defined FDI as cross border investment by a resident entity in one economy with the objective of obtaining a lasting interest in an enterprise resident in another economy. They stressed that the lasting interest implies the existence of a long-term relationship between the direct investor and the enterprise and a significant degree of influence by the direct investor on the management of the enterprise. Ownership of at least $10 \%$ of the voting power, representing the influence by the investor, is the basic criterion used.

FDI figures sourced from the Central Bank of Nigeria (CBN) shows that between 1970 and 1985, FDI fluctuated which may be due the country recovery from civil war and the indigenization policy which restricted FDI inflows to certain sectors of the economy which were exclusively left for indigenes. However, 1986 marked the deregulation of the Nigerian economy which gave room for effective and efficient economic and business activities by relaxing laws and regulations that hinder free competition in supply of goods and services. FDI data shows that the figure jumped from $\$ 4.5$ billion in 1985 to $\$ 5.0$ billion in 1986 . In 1987 , FDI increased to $\$ 5.2$ billion, which increased to $\$ 5.8$ billion in 1988 and rose up to $\$ 6.2$ billion in 1989 . The figures kept rising until 1995 which marked the enactment of the Nigerian Investment Promotion Commission (NIPC) Act, with the objective to open up all sectors to FDI, which according to United Nations Conference on Trade and Development [5] allowed for 100\% foreign ownership in all sectors, with the exception of the petroleum sector (where FDI is limited to joint ventures or production sharing). 1999 marked the return to democratic rule which was accompanied by the National Economic Empowerment and Development Strategy (NEEDS) aimed at embracing a private sector led growth strategy. Since then, FDI inflow in Nigeria have continued to be on the rise as much as $\$ 94.4$ billion in 2016.

The tremendous benefits of FDI to host states prompted successive administrations in Nigeria to pursue various reforms to attract FDI inflows. These reforms includes the deregulation of the economy, the industrial policy of 1989, the establishment of the Nigeria Investment Promotion Commission (NIPC) in 1995, and the signing of Bilateral Investment Treaties in the late 1990s [6]. These policies further included the reforms done by the Federal Government of Nigeria in 2015 to enable foreign investors on the ease of doing business in Nigeria, spearheaded by the ministry of Trade, Commerce and Investment. These reforms were articulated in strategic plans, annual budgets as well as the monetary and fiscal policies through which it attempted to control indicators like inflation, interest rates, exchange rates, aggregate spending, deficit spending and GDP growth rate. However, the World Bank report [7] noted that the Nigerian government's policy of economic deregulation and liberalization opened up new windows of opportunity to all investors wishing to invest in the country's economy. Also, on the ease of doing business 
index which rank economies against each other based on how the regulatory environment is conducive to business operations, World Bank report shows that Nigeria ranked 145 among 190 economies. This is an improvement from 169th position in 2016.

The distinction of this study from other studies on the determinants of FDI inflows in Nigeria is that there has been a period gap as most studies stopped at 2010 [6,8-10]. Beyond this period, lots of macroeconomic activities changed such as Nigeria GDP growing to become highest in Africa, depreciation of the Nigerian Naira to US dollar, increase in insecurity across the country which led to increase in military expenditure and fluctuations in government consumption expenditure. More so, giving the conflicting findings in previous studies, this study therefore, intends to fill this existing gap and in addition, includes other variables such as financial development and government consumption expenditure, military expenditure and political stability which are not common in Nigerian studies but have been identified as key determinants of FDI.

Therefore, the broad objective of this study is to investigate the determinants of FDI inflows to Nigeria.

\section{Theoretical Framework and Literature Review}

Several theories of FDI exist in literatures. Common among them includes; Product life-cycle theory, internalization theory of FDI and Eclectic theory. However, the theory that underpins this study is eclectic paradigm attributed to Dunning $[11,12]$. It provides a framework that groups micro and macro level determinants in order to analyze why and where multinational companies (MNCs) invest abroad. The framework posits that, firms invest abroad to look for three types of advantages: Ownership (O), Location (L), and Internalization (I) advantages. Hence, it is called the OLI framework. The ownership specific advantages (of property rights/patents, expertise and other intangible assets) allow a firm to compete with others in the markets it serves regardless of the disadvantages of being foreign because, it is able to have access to and exploit and export natural resources and resource-based products that are available to it. The location advantages are those that make the chosen foreign country a more attractive site for FDI than the others, hence the reason for the FDI is to supply the domestic market of the recipient country through an affiliate. The location advantages may arise from differences in country natural endowments, government regulations, transport costs, macroeconomic stability, and cultural factors. Internalization advantages on the other hand arise from exploiting imperfections in external markets, including reduction of uncertainty and transaction costs in order to generate knowledge more efficiently as well as the reduction of state-generated imperfections such as tariffs, foreign exchange controls, and subsidies.

The concept of FDI is broad and several attempts have been made by different authors to define it. This section therefore reviews some of the definitions of FDI [13] defined FDI as a package of capital, technology, management, and entrepreneurship, which permits a firm to operate and offer commodities and services in a foreign marketplace. According to him, firms seek to take advantage of a new large market, which is considered as a traditional motive for FDI. This work, however, adopts the definition by the Organization for Economic Cooperation and Development [14] which defines FDI as cross border investment by a resident entity in one economy with the aim of obtaining a durable interest in an enterprise resident in another economic system. OECD stressed that the lasting interest implies the existence of a long-term relationship between the direct investor and the enterprise and a substantial degree of influence by the direct investor on the management of the enterprise. Ownership of at least $10 \%$ of the voting power, representing the influence by the investor, is the basic criterion used.

\section{Foreign direct investment inflow in Nigeria}

The Nigerian market is a large market for investors and profit seeking co-operations. In order to place Nigeria as one of the largest economies in the world, several policies were instituted by government at various levels to achieve this goal. Efforts were made by the federal government through the Nigerian Investment Promotion Commission Act in 1995 to open different sectors of the Nigerian Economy to FDI, allowing complete ownership in all sectors (with exception to petroleum sector where FDI is limited to joint ventures or production sharing contracts) through fair treatment and tax incentives. This was aimed at promoting import substitution policy. Other laws were enacted equally to both domestic and foreign investors. They include: Banking and Other Financial Institutions Act (1991), Foreign Exchange Act (1995), Money Laundering Act (2003), Investment and Securities Act (2007), Electric Power Sector Reform Act (2005), Nigerian Mineral and Mining Act (2007), Nigeria Extractive Industries Transparency Initiative (NEITI) Act (2007), Central Bank of Nigeria Act (2007), the Nigerian Oil and Gas Content Development Act (2010).

According to UNCTAD [5] oil exploration has been the dominant target for most international commentary on FDI for the last 30 years and its impact on the Nigerian economy has been large. Beyond the oil industry, and in manufacturing in particular, foreign affiliates are few and have had no significant development impact. While foreign investors have been able to deploy capital and technology in exploration and extraction of crude oil, same cannot be said of the manufacturing sector which has been stagnated for decades. Concerning the service industry, particularly the telecommunications had a significant impact on the expansion of mobile telephone in Nigeria since its launch of Global System for Mobile (GSM) licensing in 2001. The competition among licensed firms have attracted billions of dollars into the Nigerian economy. According to UNCTAD [5] MTN alone invested more than $\$ 3$ billion into the sector.

\section{Main determinants of FDI}

Several determinants of FDI have been identified in literatures both in the context of Nigeria and the world at large. Edwin [15] argued that there are no unanimously accepted single factor that determines the flow of investment. He further stated that at best, literatures provide information on the full rate of factors that are likely to induce the flow of FDI anywhere. It is worthy of note that, not all determinants are equally important to investors in every location at all the times. However, some determinants may be more important to a given investor for a given time to another investor. Ogunleye [16] noted that while it is difficult to determine the exact quantity and quality of FDI determinants that should be present in a location for it to attract a given level of inflows, it is nevertheless clear that a critical minimum of these determinants must be present before FDI inflows begin to occur. The following are the main determinants of FDI identified in the review of various literatures.

- Market size (GDP)

- Natural resources 
- Openness

- Inflation rate

- Exchange rate

- Interest rate

- Infrastructure

- Fiscal deficit

- Debt ratio

- Size (Ratio of government consumption to GDP)

- Political stability

- Electricity consumption

- Transportation and communication

- Telephone lines

- Labour cost (wages)

- Human capital

- Corporate tax

- Bank credit

- Finance access

- Financial development

- Military expenditure

- Gross capital formation

- Export

- Import

- External Debt.

The following determinants are therefore, examined in this study to test if they exist any influence on FDI inflows in Nigeria.

Government consumption expenditure (GCE): This is measured as the ratio of Government Consumption Expenditure to GDP. It indicated the extent of government involvement in the economy which is expected to bear a direct relationship to economic growth and FDI because a higher level of government consumption should translate into provision of social infrastructure that should encourage production, growth and FDI inflows. Anyanwu [17] argued that a relative small government makes it leaner and more efficient through better remuneration packages. Hence the smaller a government, the more efficient it is perceived to be, thus creating a conducive environment for robust private investment. However, a relatively large government tends to crowd out private studies on government consumption expenditure and FDI inflows. Anyanwu [17] examined the factors that cause FDI to flow into African countries. Using OLS, results from panel regression for the period 1980-2007 indicate that, high government consumption expenditure attracts FDI inflows to Africa.

Financial development (FINDEV): Financial development is important in FDI decisions because it affects the cost structure of investment projects [18]. Kinda [19] observes that financial development is an engine of economic growth, providing better business opportunities for customers and firms. This is proxy by the ratio of domestic credit to the private sector to GDP. This is an indicator of domestic financial development, potentially an important factor in driving international finance. Anyanwu [17] stated that a high level of credit to the private sector is an indication of the abundance of domestic capital. As such, foreign capital in the form of FDI would not be needed as much, hence a negative relationship between private credit and FDI inflows. He further explained that another possible explanation is that such negative relation is another manifestation of the negative relationship that exists between FDI and other types of flows, mainly bank loans. Empirical studies such as, Shahrudin et al. [20] who examined the determinants of FDI in Malaysia for the period 1970-2008. The causality and dynamic relationships between FDI and its key determinants is identified using Autoregressive Distributed Lag (ARDL) framework. The result suggests that among the variables, financial development contribute positively to the inflow of FDI in Malaysia. Also in the study conducted by Dutta and Roy investigated the role of political risk in the association of FDI and financial development using a panel of 97 countries. The regression result showed that the impact of financial development on FDI becomes negative beyond a threshold level of financial development. Anyanwu [17] examined the factors that cause FDI to go to African countries. Using OLS, results from a panel for the period 1980-2007. The regression result indicated that higher financial development has negative effect on FDI inflows.

Economy openness (ECOPEN): The openness index is an economic metric calculated as the ratio of country's total trade measured as the sum of exports plus imports, to the country's GDP (i.e., Export +Imports)/GDP. The effect of economy openness on FDI inflows depends on the type of FDI. When a country receives market-seeking FDI, i.e., when foreign firms aim at serving local market, economy openness may reduce FDI inflows. Mijiyawa [21] argued that multinational firms that seek to service local markets may decide to set up subsidiaries in the host nation when it is hard to import their wares in that country. In contrast, multinational firms that are engaged in export-oriented activities may choose to locate in a more open economy, since trade protectionism may increase transaction costs; thereby, reducing economic competitiveness and exports. Thus, the effect of economy openness on FDI inflows is ambiguous. However, the apriori expectation is positive. Several authors have found that trade openness is a major determinant of FDI. These studies include: Uwubanmwen and Ajao [10]; Gichamo [22]; Enu et al. [23]; Blonigen and Piger [24]; Ndem et al. [8] and Maghori [25]. On the contrary, Njogo [26] found a negative and insignificant impact on FDI in Nigeria. While Abubakar and Abdullahi [27] found that openness of the economy do not attract FDI in Nigeria.

Gross domestic product (GDP): Market size and its growth is regarded as an important determinant of FDI inflows into the host country. Apriori expectation is expected to positive. Several studies carried out in this area have established a correlation between FDI and the size of the market (proxy by GDP). They include; In Malaysia, Shahrudin et al. [20] found out that economic growth contribute positively to FDI inflows. In Africa, Sichei and Kinyondo [28]; Gichamo [22] also found a positive correlation between GDP and FDI. In Nigeria, Offiong and Atsu [29]; Ndem et al. [8]; Ojong et al. [30] and Danladi and Uwaifo [31] found that economic growth has a positive impact on FDI. On the contrary, Oba and Onuoha [9] showed that GDP does not bring about FDI in Nigeria. While Uwubanmwen and Ajao [10] and Njogo [26] found economic growth had a positive but insignificant impact on FDI.

Military expenditure (MILEXP): Military expenditure also known as defense budget of a country is the amount of funds spent on equipping the military in a given year. The apriori expectation is that it negatively impacts FDI because an increase military expenditure most especially in crises prone regions discourages foreign investors from coming into the country for fear of instability. Awan et al. [32] found military expenditure increases, which depicts the foreign disinterest in Pakistan FDI inflows. 
Exchange rate (EXR): Another factor that determines FDI inflows is the exchange rate which is measured as the official exchange rate to the US dollar annual average. The apriori expectation is that high exchange rate lead to a negative influence on FDI. Wafure and Abu [6] argued that, if the exchange rate of a country depreciates, it attracts FDI since foreign firms may merge with or acquire domestic industries. Several studies have been conducted in this regards. Danladi and Uwaifo [31] examined the impact of the determinants of FDI in Nigeria. The study covers the period 1980 to 2013. Using VECM, the findings of the study revealed exchange rate have a positive relationship with FDI and exchange rate lag two have a negative relationship with FDI. Chakrabarti [33]; Dinda [34]; Wafure and Abu [6]; Uwubanmwen and Ajao [10]; Isah [35]; Ndem et al. [8] found that exchange rate impacts FDI inflows. On the contrary, Njogo [26] found a negative but non-significant impact on FDI. Ohazulike [36] found a positive but insignificant relationship with FDI.

Inflation rate (INFR): The apriori expectation is negative because high inflation rate affects investment. Idowu and Awe noted that FDI into Nigeria has been relatively low and not encouraging given the high Inflation rate. Dinda [34]; Uwubanmwen and Ajao [10]; Maghori [25] and Danladi and Uwaifo [31] found that inflation rate is major determinant of FDI in Nigeria. Ohazulike [36] found negative but significant relationship with FDI in Nigeria.

Interest rate (INR): Economic theory posits that FDI is sensitive to domestic interest rate. Uwubanmwen and Ajao [10] found that interest rate is a major determinant of FDI in Nigeria. Danladi and Uwaifo [31] found a negative impact of first and second lag interest rate on FDI inflows. They argued that a stable interest rate is necessary for attracting FDI.

Political stability (POLSTA): Political instability has to do with the abnormal changing of leaders, government policies, security issues to government and regime type [16]. The stability of political administrative regimes of a Nation has great significance to the operations of foreign firms. Based on Wafure and Abu [6] study, we assign 0 dummy to represent civilian rule while dummy 1 was used to represent military rule. Political instability has been noted by a number of researchers to have a negative and statistically significant impact on FDI. It also showed that FDI into Nigeria has been relatively low and not encouraging given the high political instability factors. Ndem et al. [8] added that political risk is unfavorable to FDI inflows. Wafure and Abu [6] found a significant impact of political instability on FDI.

\section{Methodology}

This study adopts ex-post facto research design. Secondary data were sourced from CBN library covering the period from 1986-2017. The data were first subjected to unit root test to test for stationarity using Augmented Dickey Fuller (ADF) test and Phillips Perron (PP) test in order to avoid spurious regression. Thereafter, Johansen cointegration test was employed to test the long run relationship among the variables, which informed our decision to use Error Correction Mechanism (ECM). The analysis were carried out using Eviews 8.0.

\section{Model specification}

The ECM which was developed by Engle and Granger is a means of reconciling the short run behavior of an economic variable with its long run behavior [37]. The model captures the relationship between FDI and the explanatory variables. The ECM equation is given as:

$$
\Delta Y_{t}=\alpha_{0}+\alpha_{j-k} \Delta X_{t i}+\alpha_{2} E C M+\varepsilon_{t}^{\prime}
$$

Therefore, the model that captures both the dependent and independent variable is stated below:

$$
\begin{aligned}
& F D I_{t}=\beta_{0}+\beta_{1} G D P_{t}+\beta_{2} I N F L R_{t}+\beta_{3} E X P_{t}+\beta_{4} I R_{t}+\beta_{5} O P E N_{t} \\
& +\beta_{6} F D_{t}+\beta_{7} G C E_{t}+\beta_{8} P O L S T A_{t}+\beta_{9} M E_{t}+\beta_{10} E C M_{t}+\varepsilon_{t}
\end{aligned}
$$

FDI - Denotes Foreign Direct Investment which is measured as annual FDI inflows

\section{GDP - Denotes Gross Domestic Product measured as real GDP}

EXR- Denotes exchange rate which is the official exchange rate to US\$ (Annual average)

\section{IR - Denotes interest rate which is the annual interest rate}

INFLR - Denotes inflation rate which is measured as the annual inflation rate

OPEN- Denotes openness which is the sum of export and import as a percentage of GDP

$\mathrm{FD}$ - which is financial development measured as domestic credit to the private sector as \% of GDP

GCE - Denotes government consumption expenditure measured as $\%$ of GDP

POLSTA - Denotes political instability which captures both military rule and civilian rule. Thus, Democratic rule $=0$ and military rule $=1$

ME - Denotes military expenditure

$\beta 1-\beta 9$ - Coefficient of the explanatory variables

$\varepsilon$ - Error term.

\section{Discussion of Results}

\section{Unit root test}

Before estimating the equation, the variables were subjected to stationary tests of time series in order to avoid the problem of spurious regression. If the data series is differenced and it is found to be stationary, then they can be integrated to the order of one or greater, otherwise, a non-stationary series exists. The unit roots test was evaluated using Augmented Dickey-Fuller and Phillip-Perron [38] tests which are based on the null hypotheses of non-stationarity and failure to reject the null, implies rejection and the need for appropriate differencing to induce stationarity.

Table 1 shows the stationarity test results which was carried out to test the presence of unit root which was tested at 5\% Mackinnon critical value. This study employed both ADF and PP because, the ADF is conducted by augmenting the preceding three equations by adding the lagged values of the dependent variable, the idea being to include enough terms so that the error term is serially uncorrelated. On the other hand, PP test use nonparametric statistical methods to take care of the serial correlation in the error terms without adding lagged difference terms [37]. From our analysis, all variables were found to be stationary at first difference. This outcome therefore informs our decision to conduct a cointegration test. 
Page 5 of 7

\section{Cointegration test}

Johansen cointegration was conducted to test the existence of a long run relationship among the variables. Prior to that conducting the cointegration test, we first ascertain the optimal lag length criteria for the variables using Akaike Information Criterion (AIC), Schwarz Information Criterion (SC) and Hannan-Quinn Information Criterion (HQ) criteria and it was found that 1 lag is more suitable for our analysis.

The result of the Johansen cointegration test presented in Appendix A, indicates at least 9 cointegration equation. The result therefore, confirms the existence of cointegration among the variables. Hence, we can conclude that there exists a long run relationship among variables.

\begin{tabular}{|c|c|c|c|c|}
\hline Variables & ADF t-statistics & Order & PP t-statistics & Order \\
\hline FDI & $-12.06654^{* * *}$ & $\mathrm{I}(1)$ & $-6.949881^{* * *}$ & $\mathrm{I}(1)$ \\
\hline Exr & $-3143501^{* *}$ & $\mathrm{I}(1)$ & $-3.143501^{* *}$ & $\mathrm{I}(1)$ \\
\hline GCE & $-4.995258^{\star \star *}$ & $\mathrm{I}(1)$ & $-6.885009^{* * *}$ & $\mathrm{I}(1)$ \\
\hline GDP & $-5.454176^{\star * *}$ & $\mathrm{I}(1)$ & $-5.454137^{* * *}$ & $\mathrm{I}(1)$ \\
\hline INFLR & $-6.722432^{* \star *}$ & $\mathrm{I}(1)$ & $-6.424541^{* \star *}$ & $\mathrm{I}(1)$ \\
\hline IR & $-6.280258^{* * *}$ & $\mathrm{I}(1)$ & $-6.393089^{\star \star *}$ & $\mathrm{I}(1)$ \\
\hline ME & $-7.569897^{* * *}$ & $\mathrm{I}(1)$ & $-9.092233^{* * *}$ & $\mathrm{I}(1)$ \\
\hline Open & $-3.331116^{*}$ & $\mathrm{I}(1)$ & $-6.949881^{* * *}$ & $\mathrm{I}(1)$ \\
\hline PI & $-5.477226^{* * *}$ & $\mathrm{I}(1)$ & $-5.477891^{* \star *}$ & $\mathrm{I}(1)$ \\
\hline FD & $-5.447909^{* * *}$ & $\mathrm{I}(1)$ & $-8.834956^{* * *}$ & I(1) \\
\hline
\end{tabular}

Note: ${ }^{* * *},{ }^{* *}$ and ${ }^{*}$ represent significant level at $1 \%, 5 \%$ and $10 \%$ Mackinnon critical values

Source: Eviews output (2018)

Table 1: Augmented dickey fuller and Phillips Perron unit root tests.

\section{Error correction mechanism (ECM)}

Having established the cointegrating criteria which was found to be cointegrated. ECM was therefore analysed to measures the speed of adjustment to equilibrium. The ECM is significant, if it has a negative sign which implies that the present value of the dependent variable adjust rapidly to changes in the independent variable. A higher percentage of ECM indicates a feedback of that value or an adjustment of that value from the previous period disequilibrium of the present level of the dependent variable and the present and past level of the independent variables.

Appendix A shows the result of the ECM which is in line with our a priori expectations. The negative sign of ECM value in the model shows that, the ECM is significant at $5 \%$. This implies that the present value of the independent variables adjust rapidly to changes in FDI. The ECM value of -2.322095 shows a feedback of about $232.2 \%$ of the short-run disequilibrium and inconsistencies were being corrected and incorporated into the long-run equilibrium.

The coefficient of determination denoted as R2 is 0.977 which implies that $97.7 \%$ of the total variations in FDI is accounted for by the explanatory variables: exchange rate, GDP, government consumption expenditure, inflation rate, interest rate, political stability, military expenditure, economy openness and financial development. After adjusting the R2, the total variation becomes $92.7 \%$. Also, the fitness of the model was tested using the F-statistics which shows that the model is statistically fit as indicated by the significance level of $1 \%$.

\begin{tabular}{|c|c|c|}
\hline Variables & Coefficient & t-Statistics \\
\hline $\mathrm{D}(\mathrm{FDI}(-1))$ & -2.602120 & $-2.750874^{* *}$ \\
\hline$D(E X R)$ & 1.376394 & $4.535312^{* * *}$ \\
\hline $\mathrm{D}(\operatorname{EXR}(-1))$ & -1.102865 & -1.470040 \\
\hline $\mathrm{D}(\mathrm{GCE})$ & 0.002202 & 0.295150 \\
\hline $\mathrm{D}(\mathrm{GCE}(-1))$ & -0.000714 & -0.057711 \\
\hline $\mathrm{D}(\mathrm{GDP})$ & 0.007346 & $6.802431^{\text {***}}$ \\
\hline $\mathrm{D}(\mathrm{GDP}(-1))$ & 0.002101 & $2.566541^{* *}$ \\
\hline $\mathrm{D}(\mathrm{INFLR})$ & -0.081347 & -0.585461 \\
\hline $\mathrm{D}(\operatorname{INFLR}(-1))$ & 0.002038 & 0.018091 \\
\hline $\mathrm{D}(\mathrm{IR})$ & -1.247293 & -1.633631 \\
\hline $\mathrm{D}(\operatorname{IR}(-1))$ & -0.763600 & -1.100212 \\
\hline $\mathrm{D}(\mathrm{ME})$ & $-4.77 \mathrm{E}-10$ & $-3.598387^{\star * *}$ \\
\hline $\mathrm{D}(\mathrm{ME}(-1))$ & $-2.32 \mathrm{E}-10$ & $-2.505289^{* *}$ \\
\hline $\mathrm{D}(\mathrm{OPEN})$ & -0.080610 & -0.092137 \\
\hline $\mathrm{D}(\operatorname{OPEN}(-1))$ & 0.450622 & 0.729162 \\
\hline $\mathrm{D}$ (POLSTA) & 77.81528 & $3.103546^{\star \star \star}$ \\
\hline $\mathrm{D}(\operatorname{POLSTA}(-1))$ & -49.68462 & -0.880266 \\
\hline $\mathrm{D}(\mathrm{FD})$ & 4.255127 & $3.305438^{* \star *}$ \\
\hline $\mathrm{D}(\mathrm{FD}(-1))$ & 0.356056 & 0.295557 \\
\hline $\operatorname{ECM}(-1)$ & -2.322095 & $-2.714946^{\star *}$ \\
\hline
\end{tabular}

R2 -97.7\%, Adj. R2 -92.7\%, F-statistics-19.50537***

Note: ${ }^{* * *}$ and ${ }^{* *}$ represent significant level at $1 \%$ and $5 \%$ respectively.

Source: Eviews Output (2018).

Table 2: ECM analysis.

Table 2 shows the analysis of the determinants of FDI inflows in Nigeria. The analysis shows that FDI lag one negatively influence FDI inflows in Nigeria. Result also shows that exchange rate has a positive and significant impact on FDI inflows. Implying that an increase in exchange rate depreciates local currency and thus attracts more FDI inflow in Nigeria. This has been the Nigerian experience as the Nigerian Naira has continued to depreciate over the years and an increase in the volume of FDI inflows. Wafure and Abu [6] argued that, if the exchange rate of country depreciates, it attracts FDI since foreign firms may merge with or acquire domestic industries. This finding is contrary to the apriori expectation and the findings of Danladi and Uwaifo [31]. However, several studies have found a positive impact of exchange rate on FDI inflows $[6,8,35]$. The first lag of exchange rate was found to be negative but insignificant to FDI inflows. GCE was found to be positive but insignificant while the first lag of GCE was found to be negative and insignificant. The Table 2 
shows that GDP and first lag of GDP was positive and significant to FDI inflows in Nigeria at $1 \%$ and $5 \%$ significant level respectively, which is in line with apriori expectations and findings of previous studies $[8,20,28,30]$. Based on this finding, it can be implied that GDP is a determinant of FDI inflows in Nigeria as an increase in GDP also proxy as market size in some literatures signifies that the market is large and still growing and hence attract FDI inflows. Also, inflation rate and interest rate had the apriori sign but were found to be insignificant. Military expenditure and military expenditure lag one were found to have negative and significant impact of FDI inflows in Nigeria at $1 \%$ and $5 \%$ level of significant respectively. Awan et al. [32] argued that as military expenditure increases, FDI decreases as a result of foreign disinterest in a nation plague with insecurity challenges. This has been the Nigerian experience, with cases of various levels of insecurity ranging from Niger Delta militancy activities (kidnapping of expatriates, bombing of pipelines etc.) and boko haram (bombing of towns and villages and invasion in North Eastern part of Nigeria) and various forms of insecurity in other parts of the country. This has sent a negative signal to the international community about the security level in Nigeria and consequently, discourages foreign investors from entering the market. This finding is supported by the fact that billions of dollars have been invested in equipping the military to combat these insecurity. The result shows that economy openness is insignificant to FDI inflow in Nigeria which is against our apriori expectation. However, various studies such as Uwubanmwen and Ajao [10]; Gichamo [22]; Enu et al. [23]; Blonigen and Piger [24]; Ndem et al. [8]; Magbori [25] found positive impact of openness on FDI inflows. The Table 2 also shows the result of political stability which has a positive and significant impact on FDI inflow at $1 \%$. Political instability makes government policies unstable and unpredictable, thereby discouraging foreign investors. Impliedly, since 1999, Nigeria have experience uninterrupted democratic rules coupled with distinctive investment policies to drive the economy and attract FDI. Lastly, financial development positively and significantly impacts FDI inflows in Nigeria at 1\% level of significance. Impliedly, Kinda [19] observed that financial development is an engine of economic growth, providing better business opportunities for firms and an important factor in driving international finance.

\section{Diagnostic tests}

In order to avoid spurious regression analysis, the residuals of the regression result were subjected to various diagnostic checks such as normality test, serial correlation and hetteroskedasticity test.

Normality test: In order to test whether the residuals of the ECM regression model was normally distributed, Jarque-Bera test statistic was employed. The test statistic measures the difference of the skewness and kurtosis of the series with those from the normal distribution. The result shows that the Jarque-Bera value is not significant at $1 \%, 5 \%$ and $10 \%$ significant level resulting in the failure to reject the null hypotheses which states that our model is normally distributed. Thus, result from the Jarque-Bera test revealed that our model is normally distributed (Appendix B).

Serial correlation test: The residuals of the regression equation were tested for serial correlation using the Breusch Godfrey serial correlation LM test. The null hypothesis was tested which stated that there is no serial correlation. This was necessary because, serial correlation in the residuals will lead to incorrect estimates of the standard errors, and invalid statistical inference for the coefficients of the equation. From our analysis, the null hypothesis for our regression models was accepted, which states that there was no serial correlation (Appendix C).

Heteroskedasticity test: One of the statistical assumptions of OLS is that the error terms for all observations have a common variance (homoscedastic). On the contrary, varying variance errors are said to be heteroskedastic. The heteroskedasticity was tested in the residuals of the estimations using the Breusch-Pagan-Godfrey test. Ignoring the heteroskedasticity effect on the residuals of time series may result in the loss of efficiency of the estimators. The null hypothesis was stated as there is no heteroskedasticity. From our analysis, the models had no heteroskedasticity. Hence, we could not find reasons to reject the null hypotheses because they were insignificant at $1 \%, 5 \%$ and $10 \%$ (Appendix D).

\section{Conclusion and Policy Recommendations}

The importance of FDI inflows to the Nigerian economy coupled with the security concerns which has increased military budget, and the continues uninterrupted democratic dispensation in Nigeria informed this study to investigate the effect of the determinants of FDI inflows in Nigeria spanning over the period 1986-2017. ECM model was specified and estimated to analyse the data. The variables were first subject to unit root test using ADF and PP. Result showed that all variables were found to be I(1). Thereafter, the long run relationship was tested using Johansen cointegration test which established the existence of a long run relationship between the variables. ECM analysis was performed and the findings revealed that the speed of adjustment to its long run equilibrium was corrected at $232 \%$. The result showed that exchange rate, GDP, first lag of GDP, military expenditure, first lag of military expenditure, political stability and financial development are the major determinants of FDI inflows to Nigeria. The residuals of the analysis were further subjected to various diagnostic tests such as Jarque-Bera test of normality. Bruesch-Godfrey test of serial correlation which shows that the variables have no problem of serial correlation, Breusch-Pagan-Godfrey test of Heteroskedasticity shows that there was no heteroskedasticity in the variables. Based on the findings; the following recommendations are put forward:

- The positive impact of GDP implies that GDP is a determinant of FDI inflows. Hence, the federal government through its ministries and agencies should strengthen the investment policy to collaborate with both Multi National Cooperation's and local industries to enable free flow of investment in order to boost the economy.

- Military expenditure was found to be negatively significant to FDI inflows. This is as a result of growing insecurity across the country. Therefore, government at all levels should tackle the menace of insecurity ravaging the economy and portraying the country as insecure thereby creating a secured environment for FDI inflows.

- Political stability was found to be positively significant. Therefore, democratic regimes should be sustained and investment policies should be instituted or improved on, in order to create a friendly environment to attract more FDI inflows.

- Financial development is an important determinant of FDI. Thus, the federal government should improve the quality of domestic financial system by integrating them into global financial markets to make the economy more attractive to foreign investors.

- Given the positive impact of exchange rate of FDI inflows, government through its monetary authority should ensure a 
stronger and stable Nigeria Naira against the US dollar. This would encourage foreign investors into the country knowing fully well they can invest and project their earnings.

\section{References}

1. Smith S (1997) Restrictive Policy toward Multinationals: Argentina and Korea. Case Studies in Economic Development 178-189.

2. Hayami Y (2001) Development Economics: From the Poverty to the Wealth of Nations. Oxford University Press, US.

3. Todaro MP, Stephen SC (2003) Economic Development. Pearson Education Limited, London, UK.

4. Organisation for Economic Co-operation and Development (2008). OECD Benchmark Definition of Foreign Direct Investment (4th edn.), OECD Publishing, France.

5. United Nation Conference on Trade and Development (2009) World Investment Report: Foreign Direct Investment and the challenge of investment.

6. Wafure OG, Nurudeen A (2010) Determinants of Foreign Direct Investment in Nigeria: An empirical analysis. Global Journal of Human Social Science 10: 26-34

7. World Bank Report (2003) Sustainable Development in a Dynamic World. World Bank, US.

8. Ndem SE, Onyebuchi O, Udo NC (2014) The Determinants of Foreign Direct Investment and Their Impacts on Nigerian Economy (1975-2010), Journal of Integrative Humanism 1: 74-84.

9. Oba UO, Onuoha BC (2013) The Determinants of Foreign Direct Investments (FDIs) and the Nigerian Economy. Am Int J Contemp Res 3: 165-172.

10. Uwubanmwen AE, Ajao MG (2012) The Determinants and Impacts of Foreign Direct Investment in Nigeria. International Journal of Business and Management 7: 67-77.

11. Dunning J (1979) Towards an eclectic theory of international production Some empirical tests. Journal of International Business Studies 11: 9-31.

12. Dunning J (2000) The Eclectic paradigm as an envelope for economic and business theories of MNE activity. International Business Review 9: 163-190.

13. Farrell R (2008) Japanese Investment in the World Economy: A Study of Strategic Themes in the Internationalisation of Japanese Industry. Edward Elgar, Britain.

14. Organisation for Economic Co-operation and Development (2014). Definition of FDI. OECD Publishing, France.

15. Edwin AM (2014) Foreign direct investments: A review from the Nigerian perspective. Research Journal of Business and Management 1: 318-337.

16. Ogunleye O (2014) The effect of foreign direct investment: Case study Nigeria. Masters dissertation, University of Oulu, Finland.

17. Anyanwu JC (2011) Determinants of Foreign Direct Investment Inflows to Africa 1980-2007. African Development Bank Group Working Paper Series No. 136, Tunisia.

18. Nasser OM, Gomez XG (2009) Do well-functioning financial systems affect the FDI flows to Latin America? International Research Journal of Finance and Economics 29: 60-75.

19. Kinda T (2010) Investment climate and FDI in developing countries: Firm-Level Evidence. World Development 38: 498-513.
20. Shahrudin N, Yusof Z, Satar N (2010) Determinants of Foreign Direct Investment in Malaysia: What Matters Most? International Review of Business Research Papers 6: 235-245.

21. Mijiyawa AG (2016) What drives foreign direct investments in Africa? An empirical investigation with panel data. African Development Review 27: 392-402.

22. Gichamo TZ (2012) Determinants of Foreign Direct Investment inflows to Sub-Saharan Africa: A panel data analysis. A Masters dissertation, Sodertorns University, Sweden.

23. Enu P, Havi EDK, Attah-Obeng P (2013) Impact of Macroeconomic Factors on Foreign Direct Investment in Ghana: A Cointegration Analysis. European Scientific Journal 9: 331-348.

24. Blonigen BA, Piger J (2014) Determinants of foreign direct investment. Can J Econ 47: 775-812.

25. Maghori E (2014) Determinants of Foreign Direct Investment in NigeriaEvidence from Cointegration and Error Correction Modeling. International Journal of Business and Social Science 5: 215-224.

26. Njogo BO (2013) Foreign Direct Investment determinants in pre and deregulated Nigerian economy. Ph. D Thesis, University of Nigeria, Nsukka, Nigeria.

27. Abubakar M, Abdullahi FH (2013) An Inquiry into the Determinants of Foreign Direct Investment in Nigeria. European Scientific Journal 9: 293-308.

28. Sichei MM, Kinyondo G (2012) Determinants of Foreign Direct Investment in Africa: A Panel Data Analysis. Global Journal of Management and Business Research 12: 85-97.

29. Offiong AI, Atsu IA (2014) Determinants of Foreign Direct Investment in Nigeria (1980-2011). International Review of Management and Business Research 3: 1538-1550.

30. Ojong CM, Arikpo OF, Ogar A (2015) Determinants of Foreign Direct Investment Inflow to Nigeria. Journal of Humanities and Social Science 20: $34-43$.

31. Danladi JD, Uwaifo OJ (2015) What Determines Foreign Direct Investment Inflows To Nigeria? Journal of Poverty, Investment and Development 16: 84-91.

32. Awan AG, Ahmad W, Shahid P, Hassan J (2014) Factors Affecting Foreign Direct Investment in Pakistan. International Journal of Business and Management Review 2: 21-35.

33. Chakrabarti A (2001) The determinant of foreign direct investment: Sensitivity analysis of Cross-Country Regression. Kyklos 54: 89-112.

34. Dinda S (2008) Factors determining FDI to Nigeria: An empirical investigation. Munich Personal RePEc Archive.

35. Isah W (2012) Determinants of Foreign Direct Investment in Nigeria: An empirical investigation. Masters dissertation, Eastern Mediterrranean University, Cyprus.

36. Ohazulike OK (2012) The effect of exchange rate fluctuation, infrastructures and inflation on FDI inflows into Nigeria (1986-2009). M.Sc Thesis, Department of Banking and Finance, Nnamdi Azikiwe University, Awka, Nigeria.

37. Gujarati DN (2004) Basic Econometrics (4th edn.), McGraw-Hill, New York, US.

38. Phillips PCB, Perron P (1988) Testing for a Unit Root in Time Series Regression. Biometrika 75: 335-346. 